\title{
Late proximal pulmonary artery occlusion in a child with a single chamber after a right-sided Blalock-Taussig shunt
}

\author{
Tomasz Nałęcz, Bartłomiej Mroziński, Tomasz Moszura, Michał Wojtalik \\ K. Jonscher Clinical Hospital, Poznan University of Medical Sciences, Poznan, Poland
}

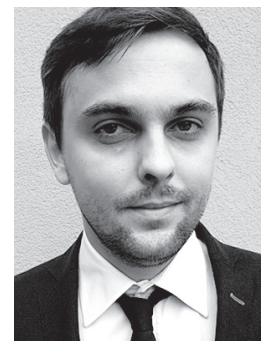

Kardiochirurgia i Torakochirurgia Polska 2016; 13 (3): 254-256

\begin{abstract}
The paper presents the management of a child born with pulmonary valve atresia, a single (double-inlet) ventricle, right ventricular hypoplasia, and perimembranous septal defect. The first stage of treatment consisted in a Blalock-Taussig shunt. Control angiography performed 1 year after surgery confirmed that the anastomosis was correct, and there was no narrowing at the connection. The first stage of treatment was complicated by the occlusion of the left pulmonary artery, as diagnosed during cardiac catheterization before the planned bidirectional Glenn anastomosis. A decision was made to perform surgery through a left thoracotomy without a cardiopulmonary bypass in order to restore the continuity of the left pulmonary artery. Key words: pulmonary atresia, pulmonary artery occlusion.
\end{abstract}

\section{Introduction}

Systemic-pulmonary anastomosis is a common palliative procedure performed when a heart defect cannot be repaired completely at a given stage of treatment. Procedures using the Blalock-Taussig shunt to anastomose the right subclavian artery with the right pulmonary artery can be complicated by coagulation in the graft that is sutured in between the vessels and by vessel stenosis at the graft location, occurring in $49 \%$ of patients (in 14\% of whom the degree of stenosis exceeds 50\%) [1].

If the tissue of the arterial duct overlaps with the left pulmonary artery, the duct's constriction and closure after the discontinuation of prostaglandin E1 infusion may cause proximal occlusion of the left pulmonary artery [2].

\section{Case report}

The patient was an 11-month-old infant with a doubleinlet ventricle, pulmonary valve atresia, right ventricular hypoplasia, a perimembranous ventricular septal defect,

\section{Streszczenie}

Przedstawiamy sposób postępowania z dzieckiem urodzonym z wrodzoną wadą serca w postaci atrezji zastawki pnia płucnego z czynnościowo wspólną komorą serca, z zachyłkiem prawej komory oraz okołobłoniastym ubytkiem międzykomorowym. Pierwszy etap leczenia stanowiło zespolenie systemowo-płucne po stronie prawej. W kontrolnej angiografii wykonanej rok po zabiegu zespolenie sposobem Blalocka-Taussig było prawidłowe, nie doszło do zwężenia w miejscu połączenia. Komplikacją po pierwszym etapie terapii okazało się proksymalne odsznurowanie lewej tętnicy płucnej zdiagnozowane w cewnikowaniu serca przed planowym zabiegiem dwukierunkowego zespolenia sposobem Glenna. Zdecydowano się na operację z lewej torakotomii bocznej bez użycia krążenia pozaustrojowego w celu odtworzenia ciągłości lewej tętnicy płucnej.

Słowa kluczowe: atrezja zastawki płucnej, udrożnienie tętnicy płucnej.

right-sided aortic arch, and aberrant left subclavian artery (Fig. 1). At the age of 27 days, the infant underwent systemic-pulmonary anastomosis between the right subclavian artery and the right pulmonary artery using a modified Blalock-Taussig shunt. The patient was admitted to the department in order to undergo control cardiac catheterization before the next stage of surgical treatment bidirectional anastomosis between the superior vena cava and the right pulmonary artery. On admission, the patient's general condition was stable; saturation: $65-70 \%$. Rhythmic heart activity (150 bpm), a murmur over the heart. A normal vesicular murmur could be heard over the lung fields. Angiography detected no inflow into the left pulmonary artery (occlusion of the left pulmonary artery); the mean pressure in the right pulmonary artery was $18 \mathrm{~mm} \mathrm{Hg}$ (Fig. 2). The results were compared with the findings of a previous angiocardiographic examination (performed after birth) and control echocardiographic examinations which revealed no abnormalities (Fig. 1). After a cardiological and cardiac surgical consultation, considering the

Address for correspondence: Tomasz Nałęcz MD, K. Jonscher Clinical Hospital, Poznan University of Medical Sciences, 27/33 Szpitalna St, 60-572 Poznan, Poland, phone: +48 502424 259, e-mail: nalecztom@gmail.com

Received: 16.12.2014, accepted: 20.05.2015. 


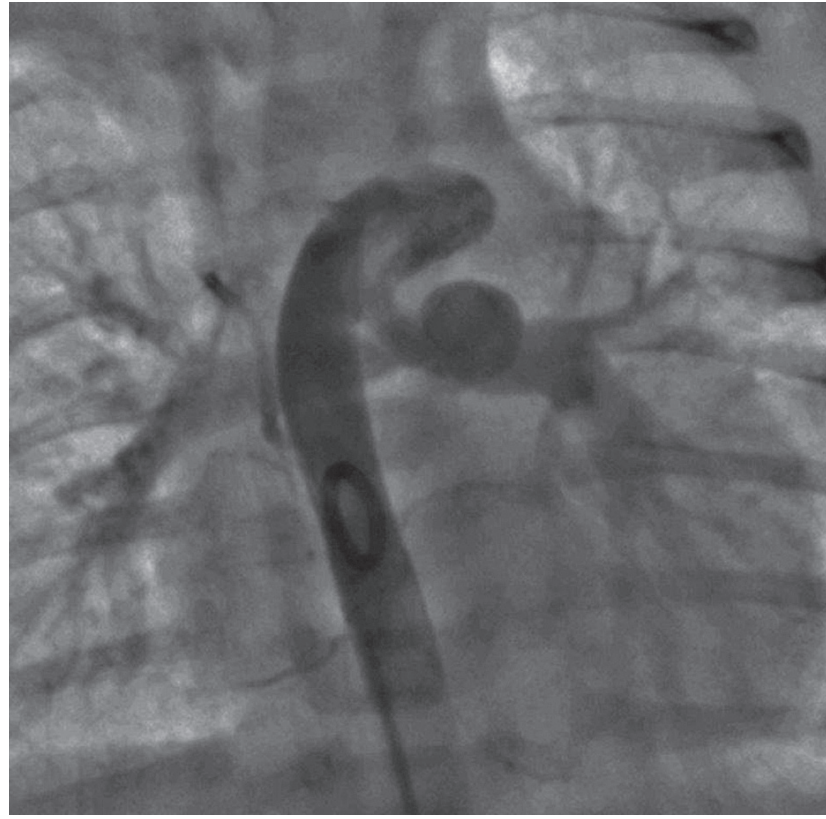

Fig. 1. Aortography: right-sided aortic arch, pulmonary arteries with contrast delivered through the patent Botal's duct; cardiac catheterization was performed after birth in order to confirm the heart defect

hemodynamics of the defect, the child was qualified for elective heart surgery to restore the continuity of the left pulmonary artery. As the left pulmonary artery could not be assessed beyond the site of occlusion, and the mean pressure in the right pulmonary artery was elevated, a decision was made not to perform a simultaneous restoration of left pulmonary artery patency and bidirectional anastomosis between the superior vena cava and the pulmonary artery. The surgery was performed when the patient was 13 months old. Due to the patent systemic-pulmonary anastomosis on the right side, blood flow and oxygenation ensured by the right lung were sufficient to allow the performance of surgery without cardiopulmonary bypass. Access to the stenosed pulmonary artery was obtained using left lateral thoracotomy. The left pulmonary artery and the stump of the pulmonary trunk were uncovered. The left pulmonary artery was clamped from the side of the pulmonary trunk and laterally with tourniquets. The site of stenosis and the tissue of the arterial ligament were excised; the pulmonary trunk was incised, and a longitudinal incision was made in the left pulmonary artery; the vessels were joined with a maximally wide anastomosis. Significant saturation drops that could endanger the patient with hypoxia were not observed during the surgery. The postoperative course was uneventful. The patient was discharged in good general condition. Follow-up examinations performed 1 year after the procedure revealed the following dimensions of the right pulmonary artery: $11 \mathrm{~mm}$ at the branching point from the trunk, $8.5 \mathrm{~mm}$ beyond the site where the anastomosis was sutured, and $10 \mathrm{~mm}$ distally. The left pulmonary artery was slightly narrower $(7.0 \mathrm{~mm}) \mathrm{ap}$ proximately $1 \mathrm{~cm}$ beyond the pulmonary trunk; distal diam-

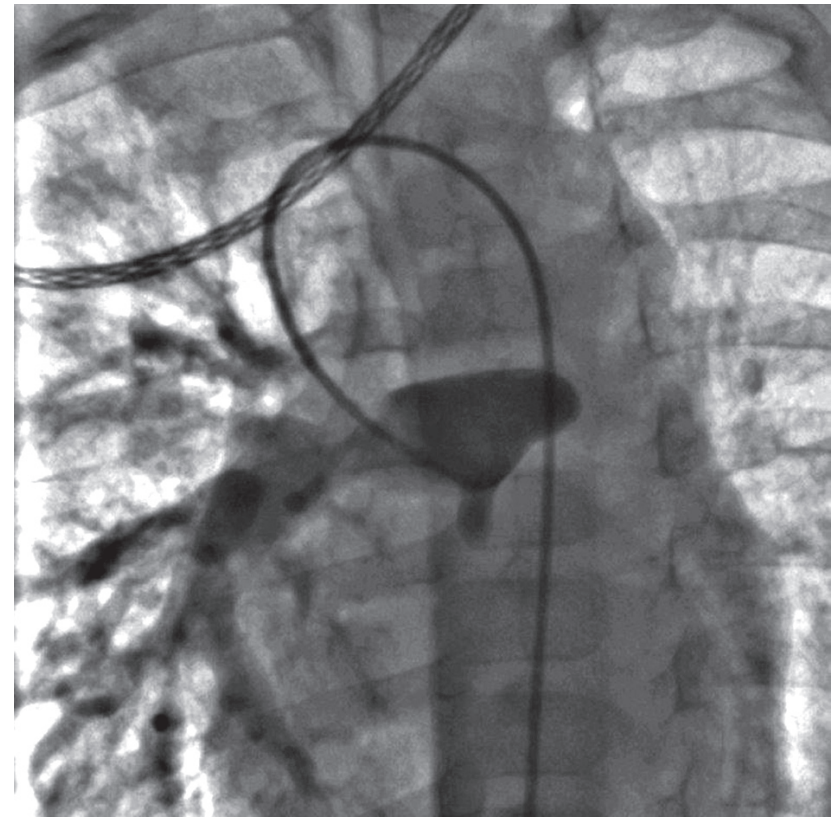

Fig. 2. Control cardiac catheterization performed before bidirectional anastomosis of the superior vena cava with the right pulmonary artery. The tip of the catheter placed in the area of the proximal left pulmonary artery; the contrast shows the right pulmonary artery, the stump of the pulmonary trunk, and the unoccluded segment of the left pulmonary artery. A decision was made to postpone the Glenn procedure, and the patient was qualified for a procedure to restore the patency of the left pulmonary artery

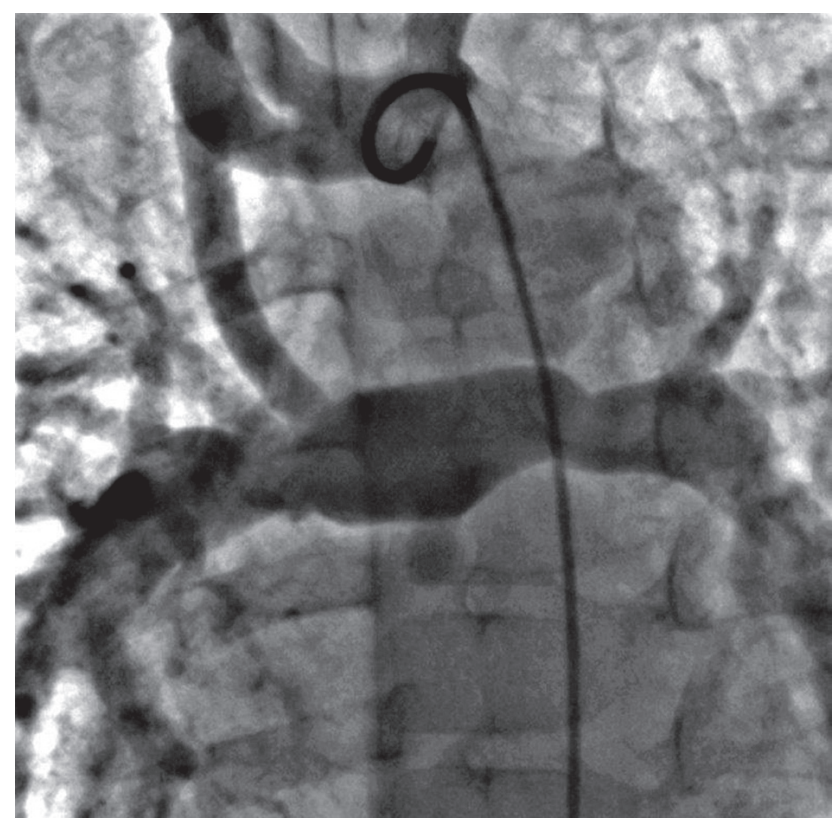

Fig. 3. Cardiac catheterization performed after the continuity of the left pulmonary artery was restored: contrast was administered to the aortic arch, visualizing the systemic-pulmonary anastomosis and the patency of the left pulmonary artery

eter: 8.5-9 mm (Fig. 3). Cardiac catheterization performed when the patient was 25 months old demonstrated that the mean pressure in the pulmonary artery was $16 \mathrm{~mm} \mathrm{Hg}$. A bidirectional anastomosis between the superior vena 
cava and the right pulmonary artery was performed at the site of the systemic-pulmonary anastomosis. Currently, the patient is being prepared for a Fontan procedure.

\section{Discussion}

In most cases, stenosis and impaired pulmonary inflow occur at the location where the graft joining the subclavian artery with the pulmonary artery is sutured [3]. In the present case, stenosis occurred not at the site of the anastomosis, but at the insertion of the arterial ligament $[4,5]$. The occlusion of the left pulmonary artery precluded the performance of the next stage of the surgical treatment for the single-ventricle heart (bidirectional anastomosis) as well as the planned subsequent stage - total cavopulmonary connection (TCPC). The patent Blalock-Taussig shunt ensured normal flow into the right lung and enabled us to perform surgery without the use of cardiopulmonary bypass; no hypoxic complications were observed. In our view, the optimal solution was to excise a fragment of the vessel with the remaining duct tissue and to perform an end-to-end anastomosis between the pulmonary arteries. Restoring the patency of the left pulmonary artery had no unfavorable effect on the development of the pulmonary vessels and did not lead to pulmonary hypertension (which would have precluded the patient from the subsequent stages of treatment).

When considering the operating strategy, we decided against performing a simultaneous restoration of left pulmonary artery patency and bidirectional anastomosis because preoperative cardiac catheterization revealed elevated arterial pressure in the right pulmonary artery $(18 \mathrm{~mm} \mathrm{Hg})$, and there was no information concerning the anatomy of the occluded segment of the left pulmonary artery, which was not visible on the obtained angiocardiogram.

Preparing the patient for the next stage of treatment (bidirectional anastomosis) required the restoration of flow in the occluded pulmonary vessel. The lack of physiological inflow into the left pulmonary artery not only impaired its development, but also caused changes in the right pulmonary artery, elevating pulmonary pressure and exerting an unfavorable effect on the single-ventricle heart [6].

\section{Conclusions}

The decision to perform the procedure without cardiopulmonary bypass reduced the risk of complications associated with extracorporeal circulation. The method had no unfavorable impact on the patient's condition; no saturation drops or postoperative complications were observed. Further examinations showed no stenosis of the operated site, which allowed the patient to be promptly prepared for the next surgery.

\section{Disclosure}

Authors report no conflict of interest.

\section{References}

1. Godart F, Qureshi SA, Simha A, Deverall PB, Anderson DR, Baker EJ, Tynan M. Effects of modified and classic Blalock-Taussig shunts on the pulmonary arterial tree. Ann Thorac Surg 1998; 66: 512-517.

2. Gowda ST, Kutty S, Ebeid M, Quereshi AM, Worley S, Latson LA. Preclosure pressure gradients predict patent ductus arteriosus patients at risk for later left pulmonary artery stenosis. Pediatr Cardiol 2009; 30: 883-887.

3. Wojtalik M, Henschke J, Skalski JH. Zabiegi łagodzące. In: Kardiochirurgia dziecięca. Religa Z, Skalski JH (eds). Wydawnictwo Śląsk, Katowice 2003; 101-112.

4. Maroto E, Fouron JC, Ake E, van Doesburg NH, Cardtwright D, Teyssier G, Bard $\mathrm{H}$. Closure of the ductus arteriosus: determinant factor in the appearance of transient peripheral pulmonarystenosis of the neonate. J Pediatr 1991; 119: 955-959.

5. Guntheroth WG. The role of ductal constriction in transient stenosis of the left pulmonary artery. Pediatr Cardiol 1998; 19: 240-242.

6. Agnoletti G, Boudjemline Y, Bonnet D, Sidi D, Vouhé P. Surgical reconstruction of occluded pulmonary arteries in patients with congenital heart disease: effects on pulmonary artery growth. Circulation 2004; 109: 2314-2318. 